\title{
Effect of different levels of nitrogen on the total polyphenol and total flavonoid content of sorghum and millet flours
}

Sz. Jevcsák ${ }^{1}$

e-mail: jevcsak@agr.unideb.hu

L. Stündl ${ }^{1}$

e-mail: sundl@agr.unideb.hu

\author{
E. Murányi ${ }^{2}$ \\ e-mail: emuranyi@agr.unideb.hu \\ J. Jóvér ${ }^{3}$ \\ e-mail: jover@agr.unideb.hu
}

P. Sipos ${ }^{4}$
e-mail: siposp@agr.unideb.hu

${ }^{1}$ University of Debrecen, Faculty of Agricultural and Food Sciences and Environmental Management, Institute of Food Technology, H-4032 Debrecen, Böszörményi St 138., Hungary

${ }^{2}$ University of Debrecen, Institutes for Agricultural Research and Educational Farm Research Institute of Karcag

${ }^{3}$ University of Debrecen, Faculty of Agricultural and Food Sciences and Environmental Management, Institute of Water and Environmental Management, H-4032 Debrecen, Böszörményi St 138., Hungary

${ }^{4}$ Agri-Corn Kft. H-4275 Monostorpályi, Szalmás tanya, Hungary

\begin{abstract}
Cereals are the most important food sources worldwide. Nowadays, there is an increase in the interest for sorghum and millet grains due to their nutritional quality and health benefits. Our aim was to determine the total polyphenol (TPC) and total flavonoid content (TFC) of sorghum and millet flours, influenced with different levels of nitrogen. The TPC of flours varied between 38.45 and $375.80 \mathrm{mg}$ GAE/100g of the selected cereal flours. The TFC ranged from 106.26 to $117.93 \mathrm{mg}$ $\mathrm{CE} / 100 \mathrm{~g}$ in sorghum and millet flours.
\end{abstract}

Keywords and phrases: polyphenol, flavonoid, cereal flours, fertilizer 


\section{Introduction}

Polyphenols have beneficial effects on the human health due to their antioxidant activity. They can remove free (mainly oxygen) radicals, inhibit the propagation of oxidation, and act as metal chelators (Alka et al., 2013; Shahidi and Ambigaipalan, 2015; Stratil et al., 2007; Pradeep et al., 2015). Flavonoids also have antioxidant properties, and they can act with other antioxidants as synergists. These flavonoid compounds, such as ferulic acid and vanillic acid, play important roles in reducing the risk and occurrence of cardiovascular diseases and cancer, and they also have an important role in the prevention of diabetes (Alka et al., 2013; Arendt and Zannini, 2013). Phenolic acids are located mainly in the pericarp and the aleurone layer in sorghum grain (Chandrashekar and Satyanarayana, 2006). The total polyphenol contents (TPC) and total flavonoid contents (TFC) of sorghum and millet are different. The TPC varies from $58 \mathrm{mg} / 100 \mathrm{~g}$ (Cardoso et al., 2014) to $128.9 \mathrm{mg} / 100 \mathrm{~g}$ (Alka et al., 2013) in sorghum flours. Millet contains $29 \mathrm{mg} / 100 \mathrm{~g}$ polyphenolics (wet basis) (Saleh et al., 2013), the TPC in millet flours is $29 \mathrm{mg}$ GAE/100g $\mathrm{dw}$ (Sharma et al., 2016), $51.4 \mathrm{mg} / 100 \mathrm{~g}$ (Chandra et al., 2016), $195.3 \mathrm{mg} / 100$ g (Alka et al., 2013). Upadhyay et al. (2015) studied the TPC of different kinds of millet flours, and it varied between 80 and $264 \mathrm{mg}$ GAE/100 $\mathrm{g}$ on dry matter. Nambiar et al. (2012) found that the total phenol content in different varieties of millet flour ranged from 268.5 to $420 \mathrm{mg} / 100 \mathrm{~g}$ of dw. Shobana and Malleshi (2007) measured the TPC in native $(265 \mathrm{mg} / 100 \mathrm{~g})$ and in decorticated $(67 \mathrm{mg} / 100 \mathrm{~g})$ millet. The TFC in sorghum flour is 45.91$58.85 \mathrm{mg} / 100 \mathrm{~g}$ (Afify et al., 2012) and $65 \mathrm{mg}$ QE/100 g, while in millet flour is $55 \mathrm{mg} \mathrm{QE} / 100 \mathrm{~g}$ (Alka et al., 2013). The experiment showed that flavonoids and phenolics could play a role in the inhibition of LDL cholesterol, DNA scission, and oxidation of liposome (Nambiar et al., 2011). As known, some anti-nutritional factors (certain phenolic compounds, fibres or phytates) could decrease the zinc and iron bioavailability (Sade, 2009), while high tannin content could reduce digestibility and food values (Osuntogun et al., 1989). Depending on localization, the decortication or milling could reduce the amount of these compounds. Our aim was to determine the total polyphenol and total flavonoid content of sorghum and millet flour samples, which were grown using different levels of nitrogen fertilizer. 


\section{Materials and methods}

\subsection{Materials}

Two varieties of Panicum miliaceum L. (Maxi and Lovászpatonai pirosmagvú) and one hybrid of Sorghum bicolor L. Moench (Zádor) were obtained from Institutes for Agricultural Research and Educational Farm, Research Institute of Karcag, University of Debrecen, in Hungary. These crops were treated by 0 (N0), $40(\mathrm{~N} 1), 80(\mathrm{~N} 2), 120(\mathrm{~N} 3), 160(\mathrm{~N} 4)$, and $200(\mathrm{~N} 5) \mathrm{kg} /$ ha nitrogen (N) fertilizer. The sizes of the parcels were $4.5 \mathrm{~m} \times 4.8 \mathrm{~m}$ for millet and $4.5 \mathrm{~m} \times$ $7.8 \mathrm{~m}$ for sorghum; each treatments were applied in four repetitions. Grains were milled by laboratory roller mill (Devisetti et al., 2014). The dry matter content of flours was $14 \%$ on average. The flour samples were kept in $4{ }^{\circ} \mathrm{C}$ until taken for analysis.

\subsection{Methods}

\subsubsection{Determination of total polyphenolic compounds}

Concentration of total phenolic compounds was determined using Folin-Ciocalteu reagent (Kim et al., 2003). The absorbance was read in a spectrophotometer $(760 \mathrm{~nm})$. The solution of gallic acid was used for the standard curve from 0 to $100 \mu \mathrm{g} / \mathrm{ml}$ concentrations. The results were expressed in $\mathrm{mg} \mathrm{GAE} / 100 \mathrm{~g}$ of flour (Cardoso et al., 2014).

\subsubsection{Determination of total flavonoid content}

Total flavonoid content was determined by spectrophotometric method (Meda et al., 2005). The absorbance was measured at $510 \mathrm{~nm}$. The standard curve was constructed between 0 and $100 \mu \mathrm{g} / \mathrm{ml}$ concentrations. The results were expressed in $\mathrm{mg} \mathrm{CE} / 100 \mathrm{~g}$ of flour $(\mathrm{CE}=$ Catechin Equivalent) (Alka et al., 2013).

The statistical analyses based on the ANOVA was carried out using Least Significant Difference $\left(\operatorname{LSD}_{5 \%}\right)$ value by Sváb (1981).

\section{Results and discussions}

\subsection{Total polyphenolic compounds}

The concentrations of total phenolic compound varied between 38.45 and $375.80 \mathrm{mg}$ GAE/100 g of selected cereals (Table 1). The sorghum hybrid flour "Zádor" showed the highest content of polyphenol, from 319.76 to $375.80 \mathrm{mg}$ 
GAE/100 g (Table 1, Figure 1). Panicum miliaceum var Maxi showed the lowest TPC content, 53.82-61.27 mg GAE/100 g and Panicum miliaceum var Lovászpatonai pirosmagvú showed the lowest content of polyphenol (38.45$53.75 \mathrm{mg}$ GAE/100 g) (Table 1, Figure 2).

Table 1: Total polyphenolic compounds (TPC) of cereal flours (mg GAE/100 g), fresh weight

\begin{tabular}{cccc}
\hline \multirow{2}{*}{$\begin{array}{c}\text { Fertilizer dose } \\
\text { kg/ha }\end{array}$} & \multicolumn{3}{c}{ Cereal flours $^{\mathrm{a}}$} \\
\cline { 2 - 4 } & Sorghum & \multicolumn{2}{c}{ Millet $^{\mathrm{b}}$} \\
\cline { 2 - 4 } & $346.41 \pm 12.3$ & $54.68 \pm 3.0$ & $49.69 \pm 2.9$ \\
N0 & $339.81 \pm 5.8$ & $56.34 \pm 5.3$ & $49.82 \pm 1.4$ \\
N1 & $319.76 \pm 4.7$ & $56.25 \pm 3.3$ & $53.75 \pm 6.2$ \\
N2 & $346.66 \pm 2.8$ & $53.82 \pm 7.4$ & $43.22 \pm 4.5$ \\
N3 & $350.62 \pm 4.1$ & $59.12 \pm 7.1$ & $38.45 \pm 1.7$ \\
N4 & $375.80 \pm 8.0$ & $61.27 \pm 9.8$ & $40.23 \pm 1.9$ \\
N5 &
\end{tabular}

a: Results are the mean \pm standard deviation of four repetitions

b: LSD $_{5 \%}$ between $\mathrm{N}$ levels 11.43

c: $\mathrm{LSD}_{5 \%}$ between $\mathrm{N}$ levels $5.03, \mathrm{LSD}_{5 \%}$ between varieties 3.18 , $\mathrm{LSD}_{5 \%}$ between $\mathrm{N}$ levels*varieties 7.11

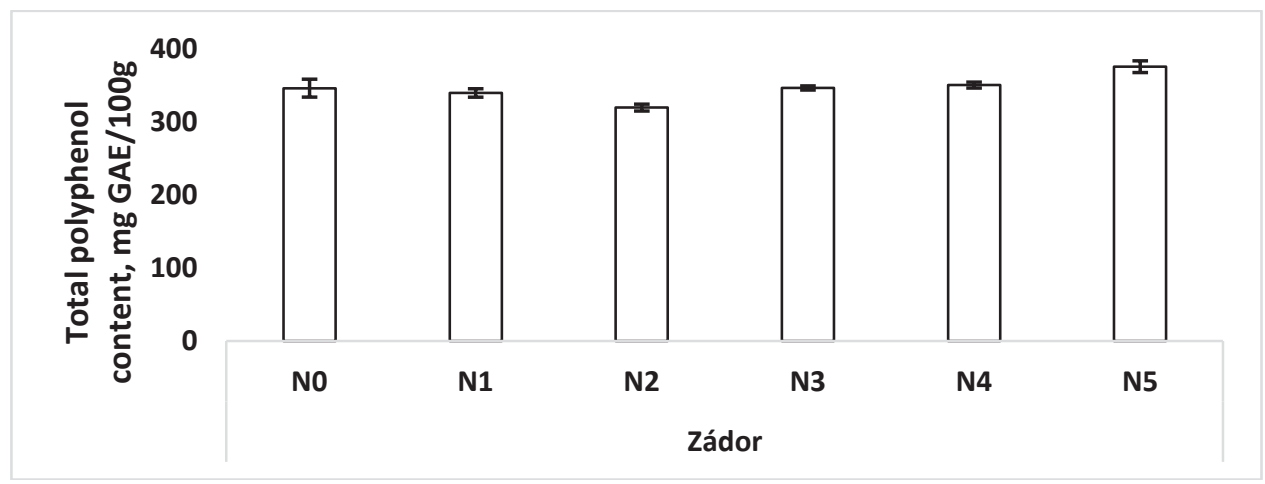

Figure 1: Total polyphenol content of sorghum flours

Significant differences were found in TPC values of "Zádor" flour samples due to the influence of various nitrogen levels ( $\left.\operatorname{LSD}_{5 \%}: 11.43\right)$. The differences between influenced millet flour samples could not reach a significant level 
$\left(\operatorname{LSD}_{5 \%}: 5.03\right)$. The differences between millet flour varieties $\left(\mathrm{LSD}_{5 \%}: 3.18\right)$, interaction of nitrogen level and varieties $\left(\mathrm{LSD}_{5 \%}: 7.11\right)$ was significant on the TPC. The TPC increased with N3-, N4-, and N5-treated samples as compared with control (N0) flour in sorghum samples (Table 1, Figure 1).

The TPC increased with increasing nitrogen level in Maxi flours, except in the sample of $\mathrm{N} 3$ fertilizer dose. The TPC increased only in the case of N1 and N2 treatments in comparison to the control sample (Table 1, Figure 2).

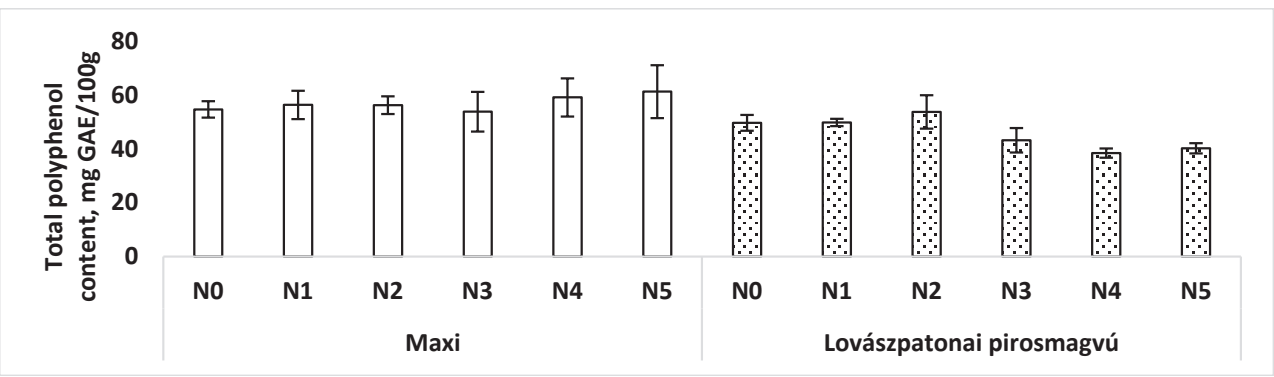

Figure 2: Total polyphenol content of millet flours

\subsection{Total flavonoid content (TFC)}

The highest TFC was showed by "Zádor" flour samples, ranging from 106.26 to $117.93 \mathrm{mg} \mathrm{CE} / 100 \mathrm{~g}$ ( Table 2, Figure 3).

Total flavonoid contents in varieties of millet flour samples were similar and varied from 10.26 to $11.46 \mathrm{mg} \mathrm{CE} / 100 \mathrm{~g}$ ( Table 2, Figure 4).

Significant differences in TFC values were found in the case of "Zádor" hybrid flours grown with different nitrogen fertilization $\left(\mathrm{LSD}_{5 \%}: 6.28\right)$. The differences between nitrogen levels ( $\left.\mathrm{LSD}_{5 \%}: 0.61\right)$, varieties $\left(\mathrm{LSD}_{5 \%}: 0.39\right)$, and interaction between nitrogen level and varieties $\left(\mathrm{LSD}_{5 \%}: 0.87\right)$ were not significant in millet flour samples.

The TFC decreased in "Zádor" flour samples, except in the flour of N2fertilized sample, where it was higher than the control sample (Table 2, Figure 3). 
Table 2: Total flavonoid content of cereal flours (mg CE/100 g), fresh weight

\begin{tabular}{|c|c|c|c|}
\hline \multirow{3}{*}{$\begin{array}{c}\text { Fertilizer dose } \\
\mathrm{kg} / \mathrm{ha}\end{array}$} & \multicolumn{3}{|c|}{ Cereal flours ${ }^{a}$} \\
\hline & Sorghum $^{b}$ & \multicolumn{2}{|c|}{ Millet $^{\mathrm{c}}$} \\
\hline & Zádor & Maxi & $\begin{array}{l}\text { Lovászpatonai } \\
\text { pirosmagvú }\end{array}$ \\
\hline N0 & $117.33 \pm 3.1$ & $10.60 \pm 0.4$ & $11.24 \pm 0.3$ \\
\hline N1 & $114.87 \pm 3.0$ & $11.14 \pm 0.6$ & $11.46 \pm 0.5$ \\
\hline $\mathrm{N} 2$ & $117.93 \pm 6.4$ & $10.85 \pm 0.7$ & $10.39 \pm 0.7$ \\
\hline N3 & $110.10 \pm 7.0$ & $10.89 \pm 0.1$ & $10.26 \pm 0.9$ \\
\hline N4 & $106.26 \pm 2.9$ & $10.87 \pm 0.2$ & $10.89 \pm 0.9$ \\
\hline N5 & $110.10 \pm 2.8$ & $10.47 \pm 0.5$ & $10.40 \pm 0.7$ \\
\hline
\end{tabular}

a: Results are the mean \pm standard deviation of four repetitions

b: LSD $_{5 \%}$ between $\mathrm{N}$ levels 6.28

c: $\mathrm{LSD}_{5 \%}$ between $\mathrm{N}$ levels $0.61, \mathrm{LSD}_{5 \%}$ between varieties 0.39 , $\mathrm{LSD}_{5 \%}$ between $\mathrm{N}$ levels*varieties 0.87
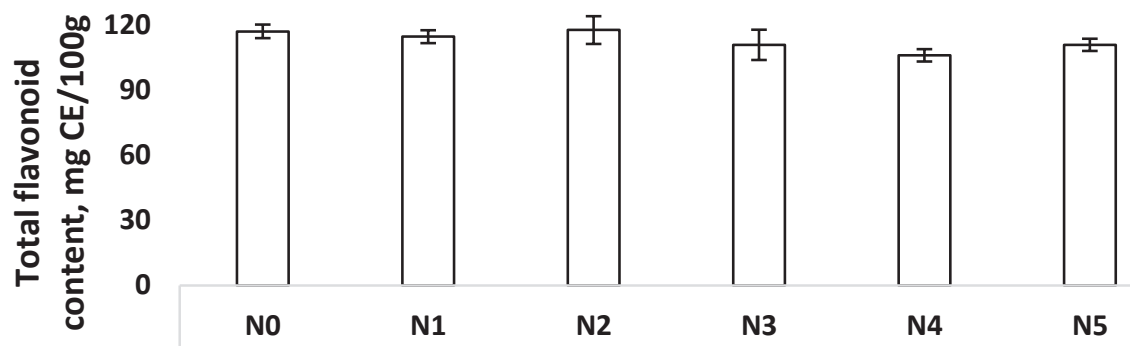

N1

N2

N3

N4

N5

Zádor

Figure 3: Total flavonoid content of sorghum flours

The TFC was approximately equal, except for N1-treated samples, where it was higher than control in both millet flours (Table 2, Figure 4). 


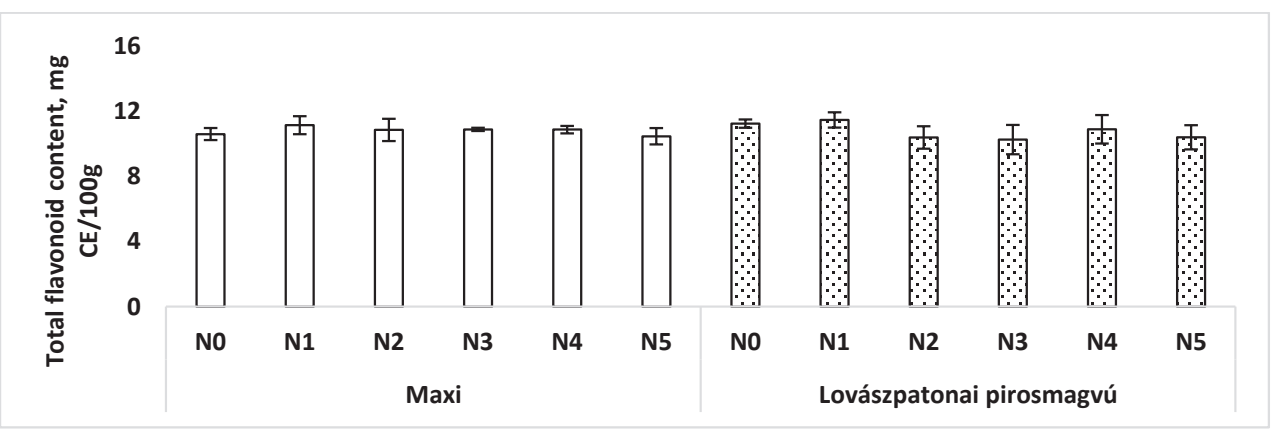

Figure 4: Total flavonoid content of millet flours

\section{Conclusions}

In our experiment, we measured the total polyphenol and total flavonoid content of sorghum and millet flour samples treated with different levels of nitrogen. Sorghum flours have higher TPC and TFC compared to the millet flour samples. The nitrogen fertilizer dose influenced the TPC values of sorghum flours (N3, N4, N5); they increased with the increasing of nitrogen level. The interactions between the influenced samples require further studying.

\section{References}

[1] S. Alka, Y. Neelam, S. Shruti, Evaluation of in vitro antioxidant profile of selected cereals. International Journal of Pharma and Bio Sciences, 4. (2013) 659-667.

[2] A. E. M. MR. Afify, H. S. E. Beltagi, S. M. A. E. Salam, A. A. Omran, Biochemical changes in phenols, flavonoids, tannins, vitamin E, $\beta$-carotene and antioxidant activity during soaking of three white sorghum varieties. Asian Pacific Journal of Tropical Biomedicine, (2012) 203-209.

[3] E. K. Arendt, E. Zannini, Cereal grains for the food and beverage industries. Millet. Woodhead Publishing Limited, (2013) 312-350.

[4] L. M. Cardoso, T. A. Monzini, S. S. Pinheiro, H. M. Pinheiro-Sant'Ana, H. S. D. Martino, A. V. B. Moreira, Effects of processing with dry heat 
and wet heat on the antioxidant profile of sorghum. Food Chemistry, 152. (2014) 210-217.

[5] D. Chandra, S. Chandra, A. K. Pallavi, Sharma, Review of finger millet (Eleusine coracana (L.) Gaertn): A power house of health-benefiting nutrients. Food Science and Human Wellness, (2016) 149-155.

[6] A. Chandrashekar, K. V. Satyanarayana, Disease and pest resistance in grains of sorghum and millets. Journal of Cereal Science, (2006) $287-304$.

[7] R. Devisetti, S. N. Yadahally, S. Bhattacharya, Nutrients and antinutrients in foxtail and proso millet milled fractions: Evaluation of their flour functionality. LWT - Food Science and Technology, 59. (2014) 889-895.

[8] D. O. Kim, S. W. Jeong, C. Y. Lee, Antioxidant capacity of phenolic phytochemicals from various cultivars of plums. Food Chemistry, 81. (2003) 321-326.

[9] A. Meda, C. E. Lamien, M. Romito, J. Millogo, O. G. Nacoulma, Determination of the total phenolic, flavonoid and proline contents in Burkina Fasan honey, as well as their radical scavenging activity. Food Chemistry, 91. (2005) 571-577.

[10] V. S. Nambiar, J. J. Dhaduk, N. Sareen, T. Shahu, R. Desai, Potential functional implications of pearl millet (Pennisetum glaucum) in health and disease. Journal of Applied Pharmaceutical Science, (2011) 62-67.

[11] V. S. Nambiar, N. Sareen, M. Daniel, E. B. Gallego, Flavonoids and phenolic acids from pearl millet (Pennisetum glaucum) based foods and their functional implications. Functional Foods in Health and Disease, 2. (2012) 251-264.

[12] B. A. Osuntogun, S. A. Adewusi, J. O. Ogundiwin, C. C. Nwasike, Effect of cultivar, steeping, and malting on tannin, total polyphenol, and cyanide content of Nigerian sorghum. Cereal Chemistry, 66. (1989) $87-89$.

[13] P. M. Pradeep, Y. N. Sreerama, Impact of processing on the phenolic profiles of small millets: Evaluation of their antioxidant and enzyme inhibitory properties associated with hyperglycemia. Food Chemistry, 169. (2015) 455-463. 
[14] F. O. Sade, Proximate, Antinutritional factors and functional properties of processed pearl millet (Pennisetum glaucum). Journal of Food Technology, 7. (2009) 92-97.

[15] A. S. M. Saleh, Q. Zhang, J. Chen, Q. Shen, Millet grains: nutritional quality, processing, and potential health benefits. Comprehensive Reviews in Food Science and Food Safety, 12. (2013) 281-295.

[16] F. Shahidi, P. Ambigaipalan, Phenolics and polyphenolics in foods, beverages and spices: Antioxidant activity and health effects - A review. Journal of Functional Foods, 18. (2015) 820-897.

[17] S. Sharma, D. C. Saxena, C. S. Riar, Analysing the effect of germination on phenolics, dietary fibres, minerals and $\gamma$-amino butyric acid contents of barnyard millet (Echinochloa frumentaceae). Food Bioscience, 13. (2016) 60-68.

[18] S. Shobana, N. G. Malleshi, Preparation and functional properties of decorticated finger millet (Eleusine coracana). Journal of Food Engineering, 79. (2007) 529-538.

[19] P. Stratil, B. Klejdus, V. Kubáň, Determination of phenolic compounds and their antioxidant activity in fruits and cereals. Talanta, 71. (2007) $1741-1751$.

[20] J. Sváb, Biometriai módszerek a kutatásban. Mezőgazdasági Kiadó, Budapest (1981).

[21] R. Upadhyay, A. Jha, S. P. Singh, A. Kumar, M. Singh, Appropriate solvents for extracting total phenolics, flavonoids and ascorbic acid from different kinds of millets. Association of Food Scientists \& Technologists, 52. (2015) 472-478. 